\title{
Correction to: An automated assessment method for integrated circuit chip detachment from printed circuit board by multistep binarization and template matching of $\mathrm{X}$-ray transmission images
}

\author{
Takao Ueda $^{1}$ (D) $\cdot$ Tatsuya Oki $^{1} \cdot$ Shigeki Koyanaka ${ }^{1}$
}

Published online: 5 December 2020

(c) The Author(s) 2020

\section{Correction to: \\ Journal of Material Cycles and Waste Management https://doi.org/10.1007/s10163-020-01131-1}

The article "An automated assessment method for integrated circuit chip detachment from printed circuit board by multistep binarization and template matching of X-ray transmission images", written by Takao Ueda, Tatsuya Oki \& Shigeki Koyanaka, was originally published electronically on the publisher's internet portal on 03 November 2020 without open access. With the author(s)' decision to opt for Open Choice the copyright of the article changed on 13 November 2020 to () The Author(s) 2020 and the article is forthwith distributed under a Creative Commons Attribution 4.0 International License, which permits use, sharing, adaptation, distribution and reproduction in any medium or format, as long as you give appropriate credit to the original author(s) and the source, provide a link to the Creative Commons licence, and indicate if changes were made.

The images or other third party material in this article are included in the article's Creative Commons licence, unless indicated otherwise in a credit line to the material. If material is not included in the article's Creative Commons licence and your intended use is not permitted by statutory regulation or exceeds the permitted use, you will need to obtain permission directly from the copyright holder.

To view a copy of this licence, visit http://creativeco mmons.org/licenses/by/4.0.

The original article can be found online at https://doi.org/10.1007/ s10163-020-01131-1.

Takao Ueda

t-ueda@aist.go.jp

1 National Institute of Advanced Industrial Science and Technology, 16-1 Onogawa, Tsukuba, Ibaraki 305-8569, Japan
The original article has been updated.

Open Access This article is licensed under a Creative Commons Attribution 4.0 International License, which permits use, sharing, adaptation, distribution and reproduction in any medium or format, as long as you give appropriate credit to the original author(s) and the source, provide a link to the Creative Commons licence, and indicate if changes were made. The images or other third party material in this article are included in the article's Creative Commons licence, unless indicated otherwise in a credit line to the material. If material is not included in the article's Creative Commons licence and your intended use is not permitted by statutory regulation or exceeds the permitted use, you will need to obtain permission directly from the copyright holder. To view a copy of this licence, visit http://creativecommons.org/licenses/by/4.0/.

Publisher's Note Springer Nature remains neutral with regard to jurisdictional claims in published maps and institutional affiliations. 